TITLE:

\title{
The first crystallographic example of a face-sharing fluoroaluminate anion Al_(2)F_(9)^(3-).
}

$\operatorname{AUTHOR}(S):$

Xu, Fei; Matsumoto, Kazuhiko; Hagiwara, Rika

\section{CITATION:}

Xu, Fei ... [et al]. The first crystallographic example of a face-sharing fluoroaluminate anion Al_(2)F_(9)^(3-).. Dalton transactions 2013, 42(6): 1965-1968

ISSUE DATE:

2013-02-14

URL:

http://hdl.handle.net/2433/182044

\section{RIGHT:}

(c) The Royal Society of Chemistry 2013; この論文は出版社版でありませ ん。引用の際には出版社版をご確認ご利用ください。; This is not the published version. Please cite only the published version. 


\section{The first crystallographic example of a face-sharing fluoroaluminate anion $\mathrm{Al}_{2} \mathbf{F}_{9}{ }^{3-}$}

Fei Xu, ${ }^{a}$ Kazuhiko Matsumoto ${ }^{* a}$ and Rika Hagiwara ${ }^{a}$

Received (in $X X X, X X X)$ Xth $X X X X X X X X X 20 X X$, Accepted Xth XXXXXXXXX $20 X X$ 


\section{Abstract}

The first example of a face-sharing fluoroaluminate anion, $\mathrm{Al}_{2} \mathrm{~F}_{9}{ }^{3-}$, is crystallographically determined in $\left[\mathrm{C}_{18} \mathrm{MIm}\right]_{3}\left[\mathrm{Al}_{2} \mathrm{~F}_{9}\right]\left(\mathrm{CH}_{2} \mathrm{Cl}_{2}\right)_{1.754}\left(\mathrm{C}_{18} \mathrm{MIm}^{+}=1\right.$-methyl-3-octadecylimidazolium cation), and the geometry and bond properties therein are discussed with the aid of quantum chemical calculations. 
The structural diversity of aluminium fluoride and fluoroaluminate anions has attracted considerable research interest, ${ }^{1-3}$ partly because of the interest in aluminium fluoride as a Lewis acidic catalyst. ${ }^{4-6}$ A large number of fluoroaluminate anions have been crystallographically determined by introducing metal or organic cations. Although the tetrahedral $\mathrm{AlF}_{4}^{-}$anion was ${ }_{5}$ determined in three salts with large organic cations, ${ }^{7,8}$ most fluoroaluminate anions consist of an octahedral $\mathrm{AlF}_{6}$ unit. ${ }^{9-14}$ The trigonal bipyramidal $\mathrm{AlF}_{5}{ }^{2-}$ anion has not been determined crystallographically, but was spectroscopically observed in a tetramethylammonium salt. ${ }^{15}$ The simplest form of fluoroaluminate anion based on the octahedral $\mathrm{AlF}_{6}$ unit is $\mathrm{AlF}_{6}{ }^{3-}$ and larger isolated species. ${ }^{16-26}$ In a few rare cases, edge-sharing bioctahedral motifs were observed in ${ }_{10}$ dinuclear, ${ }^{8,27,28}$ chain-like ch,29,30 $^{\text {and layered }}{ }^{31,32}$ structures. One of the cases missing from this series is the face-sharing structure of the bioctahedral $\mathrm{Al}_{2} \mathrm{~F}_{9}{ }^{3-}$ anion. Although such a structure was predicted in molten salts, ${ }^{33}$ no crystallographic work has been reported until now. The small ionic radii of the $\mathrm{F}$ and $\mathrm{Al}$ atoms, i.e. the short $\mathrm{Al}-\mathrm{F}$ bond, lead to difficulty in forming this type of crowded ion. In this communication, the geometry and bond properties of the first face-sharing ${ }_{15}$ fluoroaluminate anion, $\mathrm{Al}_{2} \mathrm{~F}_{9}{ }^{3-}$, are discussed in comparison with known fluoroaluminate species.

The starting compound, $\left[\mathrm{C}_{18} \mathrm{MIm}\right]\left[\mathrm{AlF}_{4}\right]$, was prepared by the reaction of $\left[\mathrm{C}_{18} \mathrm{MIm}\right]\left[\mathrm{AlCl}_{4}\right]$ and a large excess of anhydrous $\mathrm{HF}$ followed by elimination of the residual $\mathrm{HF}$ and byproduct $\mathrm{HCl}$ under vacuum. The $\mathrm{Al}_{2} \mathrm{~F}_{9}{ }^{3-}$ anion was determined in $\left[\mathrm{C}_{18} \mathrm{MIm}\right]_{3}\left[\mathrm{Al}_{2} \mathrm{~F}_{9}\right]\left(\mathrm{CH}_{2} \mathrm{Cl}_{2}\right)_{n}$, which was obtained during an attempt to grow single crystals of $\left[\mathrm{C}_{18} \mathrm{MIm}\right]\left[\mathrm{AlF}_{4}\right]$ (1-methyl-3-octadecylimidazolium ${ }_{20}$ tetrafluoroaluminate) by slow evaporation of the solvent from a $\mathrm{CH}_{2} \mathrm{Cl}_{2}$ solution. + Two $\mathrm{CH}_{2} \mathrm{Cl}_{2}$ molecules are found in the asymmetric unit, but their site occupancies are lower than $1(0.944$ and 0.810), resulting in $n=1.754$. The site occupancies of $\mathrm{CH}_{2} \mathrm{Cl}_{2}$ seem to depend on the evacuation time, and the powder X-ray diffraction pattern of the sample after it was thoroughly pumped at room temperature was completely different from the simulated pattern from the single crystal ${ }_{25}$ structure of $\left[\mathrm{C}_{18} \mathrm{MIm}\right]_{3}\left[\mathrm{Al}_{2} \mathrm{~F}_{9}\right]\left(\mathrm{CH}_{2} \mathrm{Cl}_{2}\right)_{1.754}$. The reaction that occurred during the crystallisation is 
most probably written as:

$3\left[\mathrm{C}_{18} \mathrm{MIm}\right]\left[\mathrm{AlF}_{4}\right]+n \mathrm{CH}_{2} \mathrm{Cl}_{2}$

$$
\rightarrow\left[\mathrm{C}_{18} \mathrm{MIm}\right]_{3}\left[\mathrm{Al}_{2} \mathrm{~F}_{9}\right]\left(\mathrm{CH}_{2} \mathrm{Cl}_{2}\right)_{n}+\mathrm{AlF}_{3}
$$

${ }_{5}$ The formation of $\mathrm{Al}_{2} \mathrm{~F}_{9}{ }^{-}$and loss of $\mathrm{AlF}_{3}$ probably result from the large stabilization energy by forming a lattice including $\mathrm{CH}_{2} \mathrm{Cl}_{2}$ molecules. Crystalline $\left[\mathrm{C}_{18} \mathrm{MIm}\right]\left[\mathrm{Al}_{2} \mathrm{~F}_{9}\right]\left(\mathrm{CH}_{2} \mathrm{Cl}_{2}\right)_{n}$ with insoluble white powder (probably $\mathrm{AlF}_{3}$ ) was reproducibly obtained although the quality of the crystals was not always suitable to fully complete single-crystal X-ray diffraction analysis. The $\mathrm{Al}_{2} \mathrm{~F}_{9}{ }^{3-}$ anion consists of two face-sharing $\mathrm{AlF}_{6}$ octahedra and has a roughly $D_{3 h}$ symmetry as ${ }_{10}$ shown in Fig. 1. The six bridging $\mathrm{Al}-\mathrm{F}_{\mathrm{b}}$ bonds $(1.874(2)-1.959(3) \AA)$ and the six terminal $\mathrm{Al}-\mathrm{F}_{\mathrm{t}}$ bonds $(1.723(2)-1.750(2) \AA)$ in $\mathrm{Al}_{2} \mathrm{~F}_{9}{ }^{3-}$ are longer and shorter, respectively, than the $\mathrm{Al}-\mathrm{F}$ bond in the octahedral $\mathrm{AlF}_{6}{ }^{3-}(c a .1 .80 \AA),{ }^{10-14}$ where $\mathrm{F}_{\mathrm{b}}$ and $\mathrm{F}_{\mathrm{t}}$ denote the bridging and terminal $\mathrm{F}$ atoms in $\mathrm{Al}_{2} \mathrm{~F}_{9}{ }^{3-}$, respectively. Accordingly, the $\mathrm{F}_{\mathrm{t}}-\mathrm{Al}-\mathrm{F}_{\mathrm{t}}$ angles $\left(94.24(12)^{\circ}-99.81(13)^{\circ}\right)$ are larger than the $\mathrm{F}_{\mathrm{b}}-\mathrm{Al}-\mathrm{F}_{\mathrm{b}}$ angles $\left(74.47(10)^{\circ}-77.81(10)^{\circ}\right)$ and the two octahedra in $\mathrm{Al}_{2} \mathrm{~F}_{9}{ }^{3-}$ are slightly distorted ${ }_{15}$ from the ideal $O_{h}$ symmetry. Bond valence sums of the two $\mathrm{Al}$ atoms in $\mathrm{Al}_{2} \mathrm{~F}_{9}{ }^{3-}$ are 2.91 and 2.95 according to the literature. ${ }^{34,35}$ These values are consistent with the oxidation state of +3 for $\mathrm{Al}$ as in the cases of the isolated $\mathrm{AlF}_{4}{ }^{-}(2.98 \text { and } 3.02)^{7}$ and $\mathrm{AlF}_{6}{ }^{3-}(2.96)^{13}$ anions (see

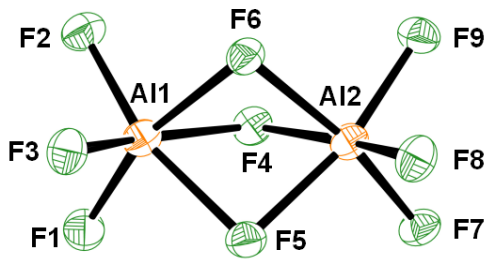

Fig. 1 The structure of $\mathrm{Al}_{2} \mathrm{~F}_{9}{ }^{3-}$ with atom numbering scheme. Selected bond lengths $(\AA)$ and angles ${ }_{20}\left(^{\circ}\right)$ : $\mathrm{Al}-\mathrm{F}_{\mathrm{t}}$ range, 1.723(2)-1.750(2); $\mathrm{Al}-\mathrm{F}_{\mathrm{b}}$ range, 1.874(2)-1.959(3); $\mathrm{F}_{\mathrm{t}}-\mathrm{Al}-\mathrm{F}_{\mathrm{t}}$ range, 94.24(12)99.81(13); $\mathrm{F}_{\mathrm{b}}-\mathrm{Al}-\mathrm{F}_{\mathrm{b}}$ range, 74.47(10)-77.81(10), where $\mathrm{F}_{\mathrm{t}}$ and $\mathrm{F}_{\mathrm{b}}$ denote terminal $(\mathrm{F} 1, \mathrm{~F} 2, \mathrm{~F} 3, \mathrm{~F} 7$, F8 or F9) and bridging F atoms (F4, F5 or F6). See Table S2, ESI $\uparrow$ for the detailed values. 


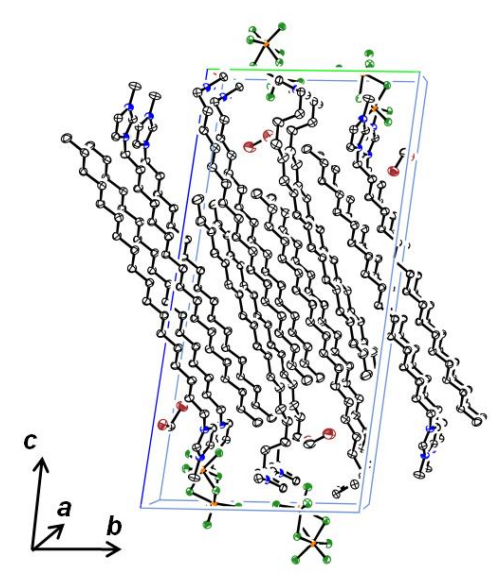

Fig. 2 Unit cell of $\left[\mathrm{C}_{18} \mathrm{MIm}\right]_{3}\left[\mathrm{Al}_{2} \mathrm{~F}_{9}\right]\left(\mathrm{CH}_{2} \mathrm{Cl}_{2}\right)_{1.754}$ at $-100{ }^{\circ} \mathrm{C}$.

Table S4, ESI $\uparrow$ for the calculation of bond valence sums).

${ }_{5}$ Such a face-sharing $\mathrm{M}_{2} \mathrm{~F}_{9}{ }^{3-}$ structure ( $\mathrm{M}$ denotes the metal atom) was observed only in three examples with transition

metals $\left(\mathrm{Cr}_{2} \mathrm{~F}_{9}{ }^{3-}, \mathrm{V}_{2} \mathrm{~F}_{9}{ }^{3-}\right.$ and $\left.\mathrm{Fe}_{2} \mathrm{~F}_{9}{ }^{3-}\right)$ when organic ammonium cations $\left(\left(\mathrm{CH}_{3}\right)_{4} \mathrm{~N}^{+}{ }^{36}\right.$ and $\left.\left(\mathrm{C}_{2} \mathrm{H}_{5}\right)_{4} \mathrm{~N}^{+}\right)^{37}$ were introduced. Although their geometries are similar, the $\mathrm{M}-\mathrm{F}_{\mathrm{t}}$ and $\mathrm{M}-\mathrm{F}_{\mathrm{b}}$ bond lengths in $\mathrm{Al}_{2} \mathrm{~F}_{9}{ }^{3-}$ are significantly shorter than those in the transition metal species $(1.987,2.033$ ${ }_{10}$ and $2.024 \AA$ for $\mathrm{Cr}-\mathrm{F}_{\mathrm{b}}, \mathrm{V}-\mathrm{F}_{\mathrm{b}}$ and $\mathrm{Fe}-\mathrm{F}_{\mathrm{b}} ; 1.838,1.852$ and $1.861 \AA$ for $\mathrm{Cr}-\mathrm{F}_{\mathrm{t}}, \mathrm{V}-\mathrm{F}_{\mathrm{t}}$ and $\mathrm{Fe}-\mathrm{F}_{\mathrm{t}}$, respectively). Consequently, the $\mathrm{M} \cdots \mathrm{M}$ distance of $\mathrm{Al}_{2} \mathrm{~F}_{9}{ }^{3-}(2.6866(19) \AA)$ is shorter than those of $\mathrm{Cr}_{2} \mathrm{~F}_{9}{ }^{3-}(2.773 \AA), \mathrm{V}_{2} \mathrm{~F}_{9}{ }^{3-}(2.852 \AA)$ and $\mathrm{Fe}_{2} \mathrm{~F}_{9}{ }^{3-}(2.907 \AA)$.

The packing mode of $\left[\mathrm{C}_{18} \mathrm{MIm}\right]_{3}\left[\mathrm{Al}_{2} \mathrm{~F}_{9}\right]\left(\mathrm{CH}_{2} \mathrm{Cl}_{2}\right)_{1.754}$ is described as the layered structure of domains with high and low polarities (Fig. 2), although this structure is not highly ordered ${ }_{15}$ compared to previously known alkylimidazolium salts with long alkyl chains, such as $\left[\mathrm{C}_{18} \mathrm{MIm}\right]\left[\mathrm{AF}_{6}\right](\mathrm{A}=\mathrm{P}, \mathrm{As}, \mathrm{Sb}, \mathrm{Nb}$, or $\mathrm{Ta}),{ }^{38}\left[\mathrm{C}_{12} \mathrm{MIm}\right]\left[\mathrm{PF}_{6}\right]^{39}$ and $\left[\mathrm{C}_{14} \mathrm{MIm}\right]\left[\mathrm{PF}_{6}\right] .{ }^{40}$ The highly polar domains, consisting of $\mathrm{Al}_{2} \mathrm{~F}_{9}{ }^{3-}$ anions and imidazolium headgroups, are separated by the low polar domains consisting of interdigitated alkyl chains tilted relative to the polar domain. There are three crystallographically independent cations in the unit cell; the alkyl chain of one cation shows 
an all-trans conformation (Cation 1, Fig. S1(c), ESI $\dagger$ ) and those of the other two cations show bent conformations (Cation 2, bent at C36, Fig. S1(d); Cation 3, bent from C66 to C68, Fig. S1(e), ESI $\uparrow$ ). The formation of $\mathrm{Al}_{2} \mathrm{~F}_{9}{ }^{3-}$ anion may be attributed to the phase separation caused by the amphiphilic cation, $\mathrm{C}_{18} \mathrm{MIm}^{+}$, which prevents the anions from coming close to each other to form ${ }_{5}$ chain-like structures. The two crystallographically independent $\mathrm{CH}_{2} \mathrm{Cl}_{2}$ molecules are located near the polar region to fill the space between the alkyl chains.

All the F atoms in the anion are involved in short contacts (below the sum of van der Waals radii, Table S3, ESI $\dagger$ ) with $\mathrm{H}$ atoms of the imidazolium rings (F2, F3, F4, F5, F7, F8 and F9), alkyl chains (F1, F2, F4, F6, F8 and F9) or $\mathrm{CH}_{2} \mathrm{Cl}_{2}$ molecules (F3, F8 and F9). Bifurcation of the $\mathrm{C}-$ ${ }_{10} \mathrm{H} \cdots \mathrm{F}$ bonds is observed for $\mathrm{H}$ atoms which interact with two $\mathrm{F}$ atoms (H2 with $\mathrm{F} 4$ and F9, H24a with F2 and F4, H32 with F8 and F9, H34 with F3 and F5, H62 with F4 and F7 and H91b with F8 and F9).

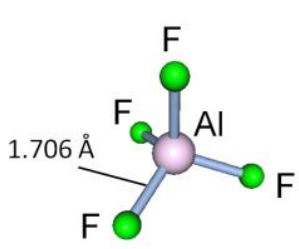

(a) $T_{d}$

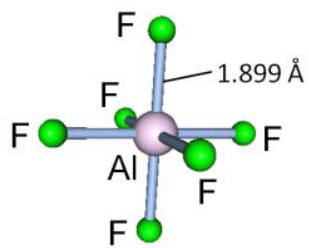

(b) $\mathrm{O}_{h}$

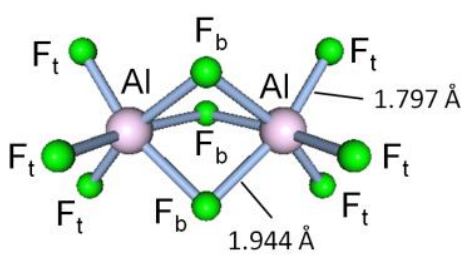

(c) $D_{3 h}$

Fig. 3 Calculated geometries of (a) $\mathrm{AlF}_{4}{ }^{-}$, (b) $\mathrm{AlF}_{6}{ }^{3-}$ and (c) $\mathrm{Al}_{2} \mathrm{~F}_{9}{ }^{3-}$ at $\mathrm{MP} 2 /$ aug-cc-pVTZ. The $\mathrm{F}_{\mathrm{t}}-$ ${ }_{15} \mathrm{Al}-\mathrm{F}_{\mathrm{t}}$ and $\mathrm{F}_{\mathrm{b}}-\mathrm{Al}-\mathrm{F}_{\mathrm{b}}$ angles in $\mathrm{Al}_{2} \mathrm{~F}_{9}{ }^{3-}$ are $75.1^{\circ}$ and $96.2^{\circ}$, respectively.

The calculated geometries of $\mathrm{AlF}_{4}{ }^{-}, \mathrm{AlF}_{6}{ }^{3-}$ and $\mathrm{Al}_{2} \mathrm{~F}_{9}{ }^{3-}$ at MP2/aug-cc-pVTZ are shown in Fig. 3 (see Table S5, ESI $\uparrow$ for detailed geometrical parameters and vibrational frequencies calculated 
at the MP2, B3LYP and PBE1PBE levels combined with cc-pVTZ and aug-cc-pVTZ basis sets). The calculated Al-F bond lengths in these species were slightly overestimated at all levels of theory compared to the experimental data. The $\mathrm{F}_{\mathrm{b}} \cdots \mathrm{F}_{\mathrm{b}}$ distance in $\mathrm{Al}_{2} \mathrm{~F}_{9}{ }^{3-}(2.368 \AA)$ is significantly shorter than the $\mathrm{F} \cdots \mathrm{F}$ distance in $\mathrm{AlF}_{4}^{-}(2.786 \AA)$ and the cis-F $\cdots \mathrm{F}$ distance in $\mathrm{AlF}_{6}{ }^{3-}(2.686 \AA)$, ${ }_{5}$ which is indicative of the steric crowding at the triply bridged part of $\mathrm{Al}_{2} \mathrm{~F}_{9}{ }^{3-}$. Natural bond orbital (NBO) charges, valencies and bond orders of the three species are listed in Table $1 .{ }^{41,42}$ In all the cases, the difference between the formal charges ( +3 for $\mathrm{Al}$ and -1 for $\mathrm{F}$ ) and $\mathrm{NBO}$ charges suggests the polar covalent nature of these $\mathrm{Al}-\mathrm{F}$ bonds. Although the $\mathrm{Al}$ atoms in $\mathrm{Al}_{2} \mathrm{~F}_{9}{ }^{3-}$ and $\mathrm{AlF}_{6}{ }^{3-}$ have similar positive charges $\left(2.024\right.$ for $\mathrm{Al}_{2} \mathrm{~F}_{9}{ }^{3-}$ and 2.049 for $\mathrm{AlF}_{6}{ }^{3-}$ ), the $\mathrm{F}$ atoms in ${ }_{10} \mathrm{Al}_{2} \mathrm{~F}_{9}{ }^{3-}$ are less negatively charged $\left(-0.808\right.$ for $\mathrm{F}_{\mathrm{t}}$ and -0.734 for $\left.\mathrm{F}_{\mathrm{b}}\right)$ than that in $\mathrm{AlF}_{6}{ }^{3-}(-0.842)$. The smaller NBO charge of $\mathrm{F}_{\mathrm{t}}$ in $\mathrm{Al}_{2} \mathrm{~F}_{9}{ }^{3-}$ relative to that in $\mathrm{AlF}_{6}{ }^{3-}$ is caused by the shorter $\mathrm{Al}-\mathrm{F}$ bond, whereas the NBO charge of $F_{b}$ is determined by the balance of two factors: the longer $\mathrm{Al}-\mathrm{F}_{\mathrm{b}}$ bond and the sharing of $\mathrm{F}_{\mathrm{b}}$ between the two $\mathrm{Al}$ atoms. $\mathrm{By}$ forming the $\mathrm{Al}_{2} \mathrm{~F}_{9}{ }^{3-}$ bioctahedral structure, the $\mathrm{Al}-\mathrm{F}$ bond order decreases from 0.376 to 0.286 for $\mathrm{Al}-\mathrm{F}_{\mathrm{b}}$ and increases from 0.376 ${ }_{15}$ to 0.415 for $\mathrm{Al}-\mathrm{F}_{\mathrm{t}}$, which indicates that the $\mathrm{Al}-\mathrm{F}_{\mathrm{b}}$ and $\mathrm{Al}-\mathrm{F}_{\mathrm{t}}$ bonds become more and less polar, respectively. These changes in bond order reflect the changes in bond length. Consequently, the valency (the sum of bond orders) of the $\mathrm{Al}$ atom in $\mathrm{Al}_{2} \mathrm{~F}_{9}{ }^{3-}$ (2.104) is smaller than that in $\mathrm{AlF}_{6}{ }^{3-}$ (2.257). The $\mathrm{Al}-\mathrm{F}$ bond in the tetrahedral $\mathrm{AlF}_{4}{ }^{-}$exhibits the largest bond order of 0.498 among the three species, which results from the short Al-F bond in this sterically less crowded species.

${ }_{20}$ In summary, the first face-sharing fluoroaluminate anion, $\mathrm{Al}_{2} \mathrm{~F}_{9}{ }^{3-}$, was crystallographically determined in $\left[\mathrm{C}_{18} \mathrm{MIm}\right]_{3}\left[\mathrm{Al}_{2} \mathrm{~F}_{9}\right]\left(\mathrm{CH}_{2} \mathrm{Cl}_{2}\right)_{1.754}$. It consists of two face-sharing $\mathrm{AlF}_{6}$ octahedra and has a roughly $D_{3 h}$ symmetry. The two $\mathrm{AlF}_{6}$ units in $\mathrm{Al}_{2} \mathrm{~F}_{9}{ }^{3-}$ are distorted from the ideal octahedral geometry and corresponding changes in bond order were observed. 
Table 1 Natural bond orbital charges, valencies and bond orders for $\mathrm{AlF}_{4}{ }^{-}, \mathrm{AlF}_{6}{ }^{3-}$ and $\mathrm{Al}_{2} \mathrm{~F}_{9}{ }^{3-}$ at MP2/aug-cc-pVTZ (see Fig. 3 for the naming of the atoms and Table S5, ESI $\uparrow$ for the other results).

\begin{tabular}{|c|c|c|}
\hline & $\begin{array}{c}\text { Charges } \\
{\text { [Valencies }{ }^{a}}\end{array}$ & Bond orders $^{b}$ \\
\hline \multirow{3}{*}{$\mathrm{Al}$} & \multicolumn{2}{|c|}{$\mathrm{AlF}_{4}^{-}\left(T_{d}\right)$} \\
\hline & 2.108 & \\
\hline & [1.992] & \\
\hline \multirow{2}{*}{$\mathrm{F}$} & -0.777 & \\
\hline & [0.498] & \\
\hline \multirow[t]{2}{*}{$\mathrm{Al}-\mathrm{F}$} & \multirow{2}{*}{\multicolumn{2}{|c|}{$\mathrm{AlF}_{6}^{3-}\left(O_{h}\right)$}} \\
\hline & & \\
\hline $\mathrm{Al}$ & $\begin{array}{r}2.049 \\
\end{array}$ & \\
\hline \multirow{2}{*}{$\mathrm{F}$} & $\begin{array}{l}{[2.25 /]} \\
-0.842\end{array}$ & \\
\hline & {$[0.376]$} & \\
\hline \multirow[t]{2}{*}{$\mathrm{Al}-\mathrm{F}$} & \multirow{2}{*}{\multicolumn{2}{|c|}{$\mathrm{Al}_{2} \mathrm{~F}_{0}{ }^{3-}\left(D_{3 b}\right) 0.376$}} \\
\hline & & \\
\hline $\mathrm{Al}$ & 2.024 & \\
\hline \multirow{2}{*}{$\mathrm{F}_{\mathrm{t}}$} & $\begin{array}{l}{[2.104]} \\
-0.808\end{array}$ & \\
\hline & [0.415] & \\
\hline $\mathrm{F}_{\mathrm{b}}$ & $\begin{array}{l}-0.734 \\
-0.5721\end{array}$ & \\
\hline $\mathrm{Al}-\mathrm{F}_{\mathrm{t}}$ & & 0.415 \\
\hline $\mathrm{Al}-\mathrm{F}_{\mathrm{b}}$ & & 0.286 \\
\hline $\begin{array}{l}{ }^{a} \text { Only the Al- } \\
\text { other minor } \\
\text { overlap-weigh }\end{array}$ & $\begin{array}{l}\text { vere considered } \\
\text { tions are ign } \\
\text { atomic orbital bc }\end{array}$ & $\begin{array}{l}\text { ation of valen } \\
\text { ere. } b \text { Ato } \\
\text { s. }\end{array}$ \\
\hline
\end{tabular}




\section{Notes and references}

${ }^{a}$ Graduate School of Energy Science, Kyoto University, Yoshida, Sakyo-ku, Kyoto 606-8501, Japan.

Fax: +81 75-753-5906; Tel: +81 75-753-4817; E-mail: k-matsumoto@energy.kyoto-u.ac.jp

$\dagger$ Electronic Supplementary Information (ESI) available: Additional experimental details, ${ }_{5}$ computational and crystallographic data. CCDC 906618. For ESI and crystallographic data in CIF or other electronic format see DOI: 10.1039/b000000x/.

†Experimental details are described in ESI $\uparrow$. Crystal data for $\left[\mathrm{C}_{18} \mathrm{MIm}\right]_{3}\left[\mathrm{Al}_{2} \mathrm{~F}_{9}\right]\left(\mathrm{CH}_{2} \mathrm{Cl}_{2}\right)_{1.754}$ : $\mathrm{C}_{67.75} \mathrm{H}_{132.51} \mathrm{~N}_{6} \mathrm{~F}_{9} \mathrm{Al}_{2} \mathrm{Cl}_{3.51}, M=1380.67$, triclinic, space group $P-1$ (no. 2), $a=8.8125(6) \AA, b=$ 14.8052(10) $\AA, c=30.847(2) \AA, \alpha=96.083(2)^{\circ}, \beta=99.426(2)^{\circ}, \gamma=90.012(2)^{\circ}, V=3947.3(5) \AA^{3}, Z=$ 10 $2 . T=173 \mathrm{~K}, D_{\mathrm{c}}=1.162 \mathrm{~g} \mathrm{~cm}^{-3}, F(000)=1495, R_{1}=0.0702$ (810 parameters), $w R_{2}=0.1752[I>$ $2 \sigma(I)], \mathrm{GOF}=1.054$ for all 12675 data. CCDC 906618.

1 A. Tressaud, Functionalized Inorganic Fluorides: Synthesis, Characterization \& Properties of Nanostructured Solids, Wiley-VCH, Weinheim, 2010.

${ }_{15} 2$ K. Adil, M. Leblanc, V. Maisonneuve and P. Lightfoot, Dalton Trans., 2010, 39, 5983.

3 U. Bentrup, M. Feist and E. Kemnitz, Prog. Solid State Chem., 1999, 27, 75.

4 N. Herron, D. L. Thorn, R. L. Harlow and F. Davidson, Chem. Mater., 1995, 7, 75.

5 N. Herron and W. Farneth, Adv. Mater., 1996, 8, 959.

6 E. Kemnitz, A. Kohne and E. Lieske, J. Fluorine Chem., 1997, 81, 197.

${ }_{20} 7$ N. Herron, D. L. Thorn, R. L. Harlow and F. Davidson, J. Am. Chem. Soc., 1993, 115, 3028.

8 N. Herron, R. L. Harlow and D. L. Thorn, Inorg. Chem., 1993, 32, 2985.

9 L. Schröder, G. Frenzen and W. Massa, Z. Anorg. Allg. Chem., 1993, 619, 1307.

10 G. Rother, H. Worzala and U. Bentrup, Z. Anorg. Allg. Chem., 1996, 622, 1991.

11 U. Bentrup, A. Ahmadi, H.-C. Kang and W. Massa, Z. Anorg. Allg. Chem., 1998, 624, 1465. 
12 V. W. Viebahn, Z. Anorg. Allg. Chem., 1971, 386, 335.

13 K. Adil, E. Goreshnik, S. Courant, G. Dujardin, M. Leblanc and V. Maisonneuve, Solid State Sci., 2004, 6, 1229.

14 A. A. Udovenko and N. M. Laptash, Acta Crystallogr., 2011, B67, 447.

${ }_{5} 15$ U. Groß, D. Müller and E. Kemnitz, Angew. Chem., Int. Ed., 2003, 42, 2626.

16 L.-Q. Tang, M. S. Dadachov and X.-D. Zou, Z. Kristallogr. - New Cryst. Struct., 2001, 216, 385.

17 K. Adil, A. B. Ali, G. Dujardin, R. Dhal, M. Leblanc and V. Maisonneuve, J. Fluorine Chem., 2004, 125, 1709.

18 R. Domesle and R. Hoppe, Angew. Chem., Int. Ed. Engl., 1980, 19, 489.

1019 E. Goreshnik, M. Leblanc and V. Maisonneuve, Z. Anorg. Allg. Chem., 2002, 628, 162.

20 K. Adil, M. Leblanc and V. Maisonneuve, J. Fluorine Chem., 2009, 130, 1099.

21 J. Nouet, J. Pannetier and J. L. Fourquet, Acta Crystallogr., 1981, B37, 32.

22 S. P. Thanh, J. Renaudin and V. Maisonneuve, Solid State Sci., 2000, 2, 143.

23 S. P. Thanh, F. Gaslain, M. Leblanc and V. Maisonneuve, J. Fluorine Chem., 2000, 101, 161.

${ }_{15} 24$ E. Goreshnik, M. Leblanc, E. Gaudin, F. Taulelle and V. Maisonneuve, Solid State Sci., 2002, 4, 1213.

25 K. Adil, A. Le Bail, G. Dujardin and V. Maisonneuve, Polyhedron, 2007, 26, 2493.

26 M. Kristl, A. Golobič, B. Dojer and M. Drofenik, Monatsh. Chem., 2011, 142, 755.

27 B. Adamczyk, S. I. Troyanov, M. Schneider and E. Kemnitz, Z. Anorg. Allg. Chem., 2000, 626, 202543.

28 L.-Q. Tang, M. S. Dadachov and X.-D. Zou, Z. Kristallogr. - New Cryst. Struct., 2001, 216, 389.

29 T. Loiseau, H. Muguerra, J. Marrot, G. Férey, M. Haouas and F. Taulelle, Inorg. Chem., 2005, 44, 2920.

30 A. Cadiau, A. Le Bail, A. Hémon-Ribaud, M. Leblanc, M. Body, F. Fayon, E. Durand, J.-C. Boulou 25 and V. Maisonneuve, Cryst. Growth Des., 2010, 10, 5159. 
31 R. L. Harlow, N. Herron, Z. Li, T. Vogt, L. Solovyov and S. Kirik, Chem. Mater., 1999, 11, 2562.

32 K. Adil, A. Le Bail, M. Leblanc and V. Maisonneuve, Inorg. Chem., 2010, 49, 2392.

33 R. R. Nazmutdinov, T. T. Zinkicheva, S. Y. Vassiliev, D. V. Glukhov, G. A. Tsirlina and M. Probst, Spectrochim. Acta A, 2010, 75, 1244.

s 34 I. D. Brown, J. Solid State Chem., 1974, 11, 214.

35 I. D. Brown and D. Altermatt, Acta Crystallogr., 1985, B41, 244.

36 L. Kiriazis and R. Mattes, Z. Anorg. Allg. Chem., 1991, 593, 90.

37 K. W. Krämer, R. Schenker, J. Hauser, H. Weihe, H. U. Güdel and H.-B. Bürgi, Z. Anorg. Allg. Chem., 2001, 627, 2511.

${ }_{10} 38$ F. Xu, K. Matsumoto and R. Hagiwara, Dalton Trans., 2012, 41, 3494.

39 C. M. Gordon, J. D. Holbrey, A. R. Kennedy and K. R. Seddon, J. Mater. Chem., 1998, 8, 2627. 40 J. De Roche, C. M. Gordon, C. T. Imrie, M. D. Ingram, A. R. Kennedy, F. Lo Celso and A. Triolo, Chem. Mater., 2003, 15, 3089.

41 A. E. Reed, L. A. Curtiss and F. Weinhold, Chem. Rev., 1988, 88, 899.

${ }_{15} 42$ E. D. Glendening, A. E. Reed, J. E. Carpenter and F. Weinhold, NBO, version 3.1; Gaussian, Inc.: Pittsburgh, PA, 1990. 